\title{
On the phenomenon of scientific work of Zbyszko Melosik
}

ABstract: Bogusław Śliwerski, On the phenomenon of scientific work of Zbyszko Melosik. Interdisciplinary Contexts of Special Pedagogy, no. 26, Poznań 2019. Pp. 405-439. Adam Mickiewicz University Press. ISSN 2300-391X. e-ISSN 2658-283X. DOI: https://doi.org/10.14746/ikps.2019.26.19

The subject of analyses are issues of research undertaken in scientific publications by Zbyszko Melosik from the Adam Mickiewicz University in Poznań, the content of which is of key significance to reforms in paedagogical sciences after the year 1989 in Poland, as well as to the understanding of international and domestic value of the cooperation of this scientist with academic circles. It is also an example of the establishment and evolution of the Poznan research school in culture, comparative and general paedagogy. They indicate a clear union between the conditions of sociocultural and education studies in light of the assumptions of post-modernism and critical paedagogy and the richness of sources by this author, connecting Polish paedagogical thought with the world discourse on socialisation and broadly understood education.

KEY WORDS: Paedagogy, pop culture, post-modernity, pathologies, university, higher education, scientific school, fundamentalism, multiculturality

${ }^{1}$ Full professor of the Faculty of Paedagogical Sciences of the Maria Grzegorzewska University in Warsaw, Poland. 
The university is (...) an ideal meeting-ground for teachers capable of imparting their knowledge, and well equipped to develop it by research and innovation and students entitled, able and willing to enrich their minds with that knowledge.

(Magna Charta Universitatum) ${ }^{2}$

\section{Autobiographical introduction}

As one's life passes, every scholar becomes aware of how fast time has passed from the moment they met another researcher in academic circles - and in my case, it is Zbyszko Melosik - the treatises of whom and the debate with whom significantly influenced my own approach towards science. I met the then-contemporary doctor Z. Melosik for the first time at the Faculty of Humanities of the Nicholas Copernicus University in Torun, where we came dangerous minds - from various universities (he - from the Adam Mickiewicz University of Poznań, me - from the University of Łódź) to the unique Polish Seminar "Absent discourses”, headed by professor Zbigniew Kwieciński. On the one hand, one felt an intergenerational distance with respect to the Elder Masters, authors of significant monographs, numerous articles or speeches at conferences who were known to us. On the one hand, we were accompanied by a feeling of a community of the younger generation, tied not only with the age of life, but also with the fascination of the necessity to liberate paedagogy from the arms of socialism and its remains.

We had luck to enter the new political system full of knowledge acquired earlier, the thousands of pages of scientific literature we read abroad, behind the "iron curtain": Zbyszko Melosik - mainly in the United States, me primarily in the FRG. We thus represented - as a result of reception of scientific knowledge on education - dif-

2 Magna Charta Universitatum (Great Charter of Universities), Observatory Magna Charta Universitatum, on-line at <http:/ / www.magna-charta.org/resources/ files/the-magna-charta/english $>$ [access: 17.11.2019]. 
ferent cultures of humanities and social sciences, from countries with different political systems, different approaches to paedagogy, yet perfectly complementary. We could talk and talk about the latest currents of paedagogical thought that had different historic sources, developed differently in their continents, creating a unique opportunity to quickly pick up the slack as a result of its absence from Poland. It was a time of the censorship, Marxist-Leninist indoctrination and the manipulation by political leaders, as inheritance of the People's Republic, being done away with.

We did not have to compete with each other as to who read more or faster about something important in the world, or who was better at interpreting certain works, when we had to fill in the hole left over after communism, remove the "blind spots" in science to fit in with world thought, theories, paradigms which, in a time of rising democracy and socialist paedagogy protected by the ranks of employees, could constitute an exit to freedom. I had the feeling that within the reality of the new statehood we are struggling towards a different authority for emancipation paedagogy, for which postmodernism had become a grand impulse, pretext or even justification to construct research work. Each of us reconstructed contemporary paedagogical thought in a different way and inscribed in it their own engagement either in the academic field, within the development of their own environment of university paedagogy, or additionally in the space of public and private education. Behind all this remained the "invisible hand" of liberalism and the supporting watch of prof. Z. Kwiecińskiego, who protected our contestation or radically controversial views.

We were, however, not "under the care" of the Professor, because - as Aleksander Nalaskowski poetically described it two years ago during a conference, in his paper entitled "Pedagogika $w$ cztery strony" [Paedagogy in four directions] - we were "four horsemen of the Apocalypse". The fourth one was Tomasz Szkudlarek. As A. Nalaskowski confirmed it from the perspective of time: (...) each of the horsemen, being one of the four, was different, entirely different. That might just be the only bridge of comparison. Because each of 
these "young lions" constructed something, did not enter into corporations to destroy others, was not ruthless and, serving others, did not take the throne of justice. ${ }^{3}$
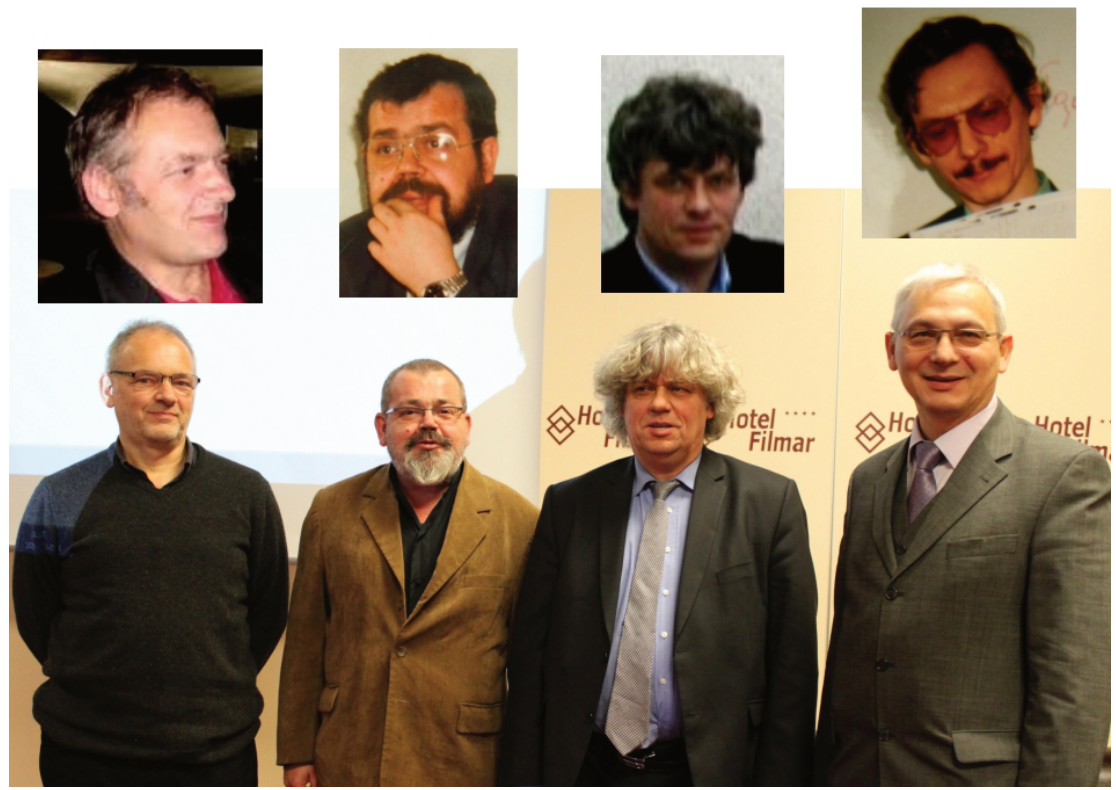

Fig. 1. From the left: T. Szkudlarek, A. Nalaskowski, Z. Melosik and B. Śliwerski, 2012 source: A. Nalaskowski)

As is clearly seen, a time of memories, generous comparisons, selfless references arose, as commenced by A. Nalaskowski as the youngest of us all. I will focus, however, on our Jubilarian. Now, my time has come to thank one of the riders of the "Wild West" for long years of cooperation and His enormous contribution to educa-

${ }^{3}$ A. Nalaskowski, Pedagogika w cztery strony (typescript of an unpublished lecture, given during the Polish Conference "Prawica-Lewica-Wychowanie” [Right wing-Left wing-Education] at the Faculty of Paedagocal Sciences of the Nicholas Copernicus University in Torun on December 5th, 2012), p. 1. 
tion sciences in our country. I will try to uncover from such a broad body of work at least some of treatises, ideas, research approaches most significant for me, but primarily for paedagogical sciences, which become an unattained form, structure and style of the phenomenal message of discourse and theory in a manner that is difficult to replicate. In Z. Melosik I respect the high literary culture, including in the area of reviews, because, like very few, he is able to share his own thoughts and opinions very truthfully, deeply and in the author's aid. He is a master of reception and explication of the most difficult issues that permeate into paedagogy from philosophy, psychology, medicine, political sciences or sociology. He handles this best, putting, to a certain extent, the research passion of his doctoral students at risk. It must not wonder that quite every doctoral student is a future, independent scientist, or even titular professor.

\section{Post-modernity as the common denominator of research and its application in science and in practice}

At this point I will not commence a dispute on whether Poland is a post-modern, post-modernist country or not, in order to show the intensely relevant scientific identity of thought with Zbyszko Melosik under different temporary and spatial conditions we got to live and work in. Thanks to the first scientific monographs of this researcher of Poznań, all of them deeply significant already, I was able to search for an answer to the question as to the extent, in which Anglo-American educational discourse arriving in Poland in the first years of the political transformation can inspire or provoke theory and transformational practice in our country; is it possible to read thanks to them a Polish-themed change in the context of issues of necessary reforms of schools and the education of teachers?

The post-modern education discourse in contemporary education sciences, initiated by Zbigniew Kwieciński, Lech Witkowski, continued by Zbyszko Melosik, fit in perfectly with the material 
reflection on the qualitative capacities of application of deep structural and methodical changes in education. ${ }^{4}$ Their treatises authorised the chances of paedagogy in a world of science, where one could be able to cross boundaries of traditional academic fields, releasing oneself at the same time from the ever-present predominance of modernist knowledge discourses. Disclosing the paedagogical potential of post-modern concepts of education along with their limitations, Melosik did not seek to crown any one of them as most significant, nor drive them away using modernist perspectives on education. Pluralism and multi-dimensionality of the sociocultural reality do not allow this discourse to take away from any of the modernist discourses acknowledged by science any sort of basis to claim the right for their analyses and value systems to be acknowledged as universal. As Z. Melosik rightly wrote:

the post-modern discourse - forgoing totality in the description of the world - hides within itself an optimistic and positive thesis: every theory may to a certain extent describe the world. The social world is not ontologically monolithical. It is diverse, complicated, internally contradictory, it is dynamic, ever open, constantly becoming. Hence, instead of accepting the assumption of a search for any megatheory or posttheoretical opinion, it seems reasonable to approve the idea that every theory can allow us to reach some sort of field of social reality or look at a specific area from a different perspective. ${ }^{5}$

${ }^{4}$ Conf.: Ku pedagogii pogranicza, ed. by Z. Kwieciński and L. Witkowski, UMK Torun 1990; Spory o edukację. Dylematy i kontrowersje we wspótczesnych pedagogiach, Selection ed. by Z. Kwieciński and L. Witkowski, IBE, Warszawa 1993; T. Szkudlarek, B. Śliwerski, Wyzwania pedagogiki krytycznej $i$ antypedagogiki, Oficyna Wydawnicza "Impuls”, Kraków 1992; T. Szkudlarek, Wiedza i wolność w pedagogice amerykańskiego postmodernizmu, Oficyna Wydawnicza „Impuls”, Kraków 1993; Nieobecne dyskursy, ed. by Z. Kwieciński, UMK Toruń, part I. - 1991, part II - 1992, part III - 1993, part IV - 1994; Z. Melosik, T. Szkudlarek, Kultura, tożsamość i edukacja. Migotanie znaczeń, Kraków: Oficyna Wydawnicza „Impuls” 1998; Z. Melosik, Wspótczesne amerykańskie spory edukacyjne, UAM, Poznań 1994; idem, Postmodernistyczne kontrowersje wokót edukacji, Wydawnictwo Edytor, Poznań-Torun 1995.

${ }^{5}$ Z. Melosik, Postmodernistyczne kontrowersje..., op. cit., pp. 20-21. 
Despite the theoretical lag of paedagogical sciences as compared to post-modern states, Polish academic circles quickly made up the distance specifically thanks to monographs of Z. Melosik, who also through his speeches during domestic conferences and paedagogical assemblies was also able to speak about metatheoretical matters in a style that was uniquely communicative and attractive. We were provided with suggestions helping us to understand real, multidimensional relations between education and knowledge on the one hand, and authority on the other; between the subject of paedagogical activity and the social structure that envelops it; he even encouraged us to work towards the creation of a "better world". No single interpretation of education can be superior to another, just as there are no "better" or "worse" theories of education or upbringing. In a pluralist and globalised world, we need to accept the existence of personal, decentralised, heterological and specifically local forms of truth, among which every one of these may be the truth for "a different version of the world".

In the same extent, my approach to education and education science was identical to that of Zbyszko Melosik, the core of which was to cause, thanks to actual, relevant education discourse, Polish education science to be liberated from the complex of being the "inferior other" and for it to become a permanently experimenting scientific discipline that reinforces creative practice and allows diverse theoretical discourses and meta-reflections to permeate into it. The education scientist from Poznań aptly suggested to me that paedagogy as well must let go of the desire to aspire to completely encompass the education reality and to reform it from the top down. Thanks to his treatises, I could much better understand the possibilities of usage in education of such discourses as: poststructuralism as a theory of social life and its educational contexts; post-modernist controversies surrounding global education; global ecology as a post-modern challenge for eco-education; multi-cultural education along with its struggle for the shape of the politics of representation; education and the make-believe culture; the postmodern world of consumption; popular culture along with its 
paedagogical potential and youth music as the post-modern cultural test. Travelling different concepts, one can note that what was "key" for one, is already "marginalised" in another; what is "macro" in one, is "micro" in another. "Entering" languages offered to us by diverse discourses we see the richness of meanings the world in which we live is being described with. Such a journey teaches one humility towards the world - it is too complicated and internally contradictory, distributed and decentralised to be "totalised" into a single narration. 6

The post-modern discourse reconstructed by Z. Melosik finally exposed mutual relations between paedagogy/ education and emancipation. The latter is, in fact, one of the fundamental objectives and reference systems of the majority of didactic theories and practices in the post-modern world. If one, as a paedagogue, would like to guide local, non-totalising politics and education, then they could become aware of the problems and dilemmas that await them. If, in fact, post-modernity removes universal values, then projects of paedagogical activities should find their substantiation in the idea of "local" emancipation. Within this context, paedagogues could consciously take the risk of a struggle for the shape of narrations typical for our society, starting with values characteristic for our society and the country we live in. Educational projects thus need not be based on essential values and concepts, and teachers were not expected to aspire to "bring in" portions of a specific discourse into the people's consciousness. A paedagogue would also be aware of the fact that the world and its truths are socially constructed in one way or another, and that in this regard they could take on the role of a conscious participant in the struggle for the shape of the "current version of reality". ${ }^{7}$ The educator or teacher assuming a post-modern version of their own paedagogy would thus have to be aware of the fact that they will live within the context of permanent risk and uncertainty.

For the first time, educators of the post-socialist period had the opportunity of aesthetic yet post-modern contact with a scientific

\footnotetext{
${ }^{6}$ Ibidem, p. 285.

7 Ibidem, p. 279.
} 
publication devoted to the humanities at the conclusion of modernity, which Z. Melosik authored together with T. Szkudlarek. Their book was the first post-modernly written work in Polish paedagogy, to which the authors attached a disc with the entire work. Why? In order to encourage readers to enter into intertextual dialogue. Their invitation was clear: Enter yourself into our text, add yourself, modify it, edit it, transform it, flip it, erase it, do what you want. We do not pretend to have the right to the "final word". We release this text into time and space. ${ }^{8}$ This was no coyness or any sort of commercial "winking" at the recipient, because both authors (some of Poland's youngest professors in paedagogy) were known for their humility and, what's rare in the circles, openness to actual dialogue.

Already in the introduction to the book, they stated the enormous joy they experienced with the experiment of co-constructioon of the text, when they would sent a fragment or a part to one another on a disk, consenting to the partnerly modification of it. As it turned out, what one wrote, for them a thread in a personal analysis, the other modified, amended, redistributed accents, led the paths of narration in a slightly different direction ${ }^{9}$. Is it not the perfect example of what did transpire over the next few years in the broader (public) scope, when the on-line availability of works (research results) of scientists became more available and intertextual for their addressees? Hence, no individual fragment has a single author. The author is always dual (or - to voice the statement radically - this text has no author). The "nonmodernity" of this path of emergence of the text on the one hand is "post"- modern (rescinding authorship is a sign of the times of postmodern culture, as is writing text exclusively on the screen). ${ }^{10}$

Reading and interpreting the text or its fragments and using the electronic capacity to immediately become part of the content, without any reservations and limitations, we could adapt them ourselves to our dreams, ideas, to our knowledge or imagination.

8 Z. Melosik, T. Szkudlarek, Kultura, tożsamość i edukacja. Migotanie znaczeń, Kraków: Oficyna Wydawnicza „Impuls” 1998, p. 12.

${ }^{9}$ Ibidem, p. 9.

${ }^{10}$ Ibidem. 
Thanks to this, the book by Zbyszko Melosik and Tomasza Szkudlarek really did enter into a cycle of "intertextuality", and perhaps even lost its original authors somewhere along the way. Indeed, the form of the book was aligned with its content, faithfully recalling the spirituality of its authors, who are, after all, united through the community of the anti-fundamentalist approach to science and paedagogy. Hence, who did not yet understand or experience what post-modernity is and what effects it may bring with itself (texts, contexts and interpretations), was not dismayed by the offer made by both authors, to try to jointly walk the 'path' of thinking about the surrounding reality. We could face THEIR "truth" and "fiction" or become aware of both the metaphysical as well as the natural, ever so clear, charm of everyday life.

I recall this treatise because it is a unique narration on experiencing the ordinariness and reality of social life, of the crisis of humanities, including paedagogy, and its practical applicability in the area of school education, along with the entire context of dramas and hopes. Retreating from the modernist struggle to tame human souls and to charm readers with theory, the authors encourage us to take a deeper "breath" of alternative reality and theories and to relativise our own biography or the modes of conceptualisation of reality. They treat paedagogy as one of many cultural practices, as one of the modes of articulation of the world, as one of the forms of the politics of representation.

It is also worth reaching out to this book in order to find out why:

- even the greatest philosophies and theories do not have a chance to shape people and reality?

- paedagogical theory, different from philosophical theory, is commonly believed to be quite an unquestionable form of theory?

- even those teachers truly fond of their pupils at school have the subtlest, and through this, a very dangerous, power over them?

- the museum, being a special kind of paedagogical text, disciplines the viewer's eye, divides it and rules it? 
- a journey across multiple theories may be a source of optimism and potential knowledge of man on their own reality?

- education is inevitably political in character?

- one can design educational interventions only on the basis of a critical analysis of the paedagogies that surround us?

- in the post-modern world, values do not play a key role in processes of rooting and identification of an individual?

- life in a world devoid of stable meanings, the specifics of which are described by fragmentary media messages and the ideology of consumption, is an indication of a "pretend, nonauthentic identity"?

- decisions over the phone and law set out during conferences are the beginning of post-modernity in politics?

- the concept of freedom is the apogee of aspirations of modern humanism?

- introducing pupils into a world of "legal" culture, sanctioned by the curriculum, at the same time, in good will, we try to disinherit them from the culture with which they came to school?

Why, why, why...? Thousands of questions come to mind, attracting and yet raising austerity in alternate, in terms of excessively quick responses. The reader shall furthermore ponder such issues as sacrum and the everyday, culture and death, humbug, or chaos, satan and free will, popular culture and pop-style values. Intertextuality, the co-presence of the above dilemmas and professorial micro-stories can, within us, give rise to the will to interfere in them, or perhaps it could cause us to feel as if we ourselves were being created by some (someone's) fictions. It is hence now the readers, meaning, the paedagogues, who must decide whether they would want to include it in the biographies of the authors of the book, or perhaps enter it into their own.

Engaged at the end of the 1980s and beginning of the 1990s in favour of the grassroots class teachers' movement and proprietary curricula in education, I could - through explication and application of scientific discourses - restore the constructive rank and significance in education e.g. of the right of teachers, pupils and their par- 
ents to bear full responsibility for the choice of mode of learning, allow the actual transpiration of the freedom to be oneself and to determine one's identity independently, solidify local forms of knowledge, strip "totalising authority" away from the discourse of consumption (advertising and fashion) or maximise and experience a range of available experiences and modes of searching for expression as part of the constructivist model of proprietary education. The publications by Z. Melosik encouraged one to spread the strategy of social participation in and takeover of education in our country, to make education democratic, with participation of all subjects of education interested in it, among others, thanks to the heads of the Polish ministry of education, by them consenting to the grassroots transformation movement as a work of social transformation. The process of inclusion of patterns of change in public education proceeded from individual innovators (transformation leaders), proprietary initiatives of social actors (parents, associations or religious congregations) or scientists. I could be engaged for the benefit of initiation, publication and implementation in Poland, in the first half of 1990, of grassroots innovations through their induction (grassroots encouragement) or diffusion of the new as alternative partial or complete solutions. ${ }^{11}$

In view of $Z$. Melosik, the world is constructed antagonistically, being in constant struggle for power, domination of one discourse over another. Were one to look at diverse paedagogies from the perspective of post-structuralism, one could note that in every society, there is an ongoing discoursive struggle of different scientific "versions" of education reality for legalisation. This takes place at the expense of alternative versions, and constitutes the operation of

${ }^{11}$ See B. Śliwerski, W. Śliwerska, Edukacja w wolności, Kraków: Oficyna Wydawnicza „Impuls” 1991; B. Śliwerski, Wyspy oporu edukacyjnego, Kraków: Oficyna Wydawnicza „Impuls” 1993; idem, Edukacja autorska, Kraków: Oficyna Wydawnicza "Impuls" 1996; idem, Jak zmieniać szkołę, Kraków: Oficyna Wydawnicza „Impuls” 1997; idem, Edukacja pod prąd, Kraków: Oficyna Wydawnicza „Impuls” 2001; idem, Problemy wspótczesnej edukacji. Dekonstrukcja polityki oświatowej III RP, Warszawa: WAiP 2009. 
their "exclusion and inclusion", meaning, it protects certain interpretations, marginalises others and forces one to go silent. The meta-narration of social life created in this manner represses its alternative versions. Alternative paedagogy, in confrontation with the top-down reforms implemented by one government after another, always belonged to the reality that was outlawed by the exclusion of the discoursive practices that create it. Proponents of alternative theories utilise usually very different epistemological, moral and ideological perspectives. (...) At that time, very frequently, theories are transformed into conceptual and strategic ideologies. As B. Mercer vividly writes, "the pages of academic journals and scientific papers (...), seminar halls (...), see passionate accusations being hurled from the fortifications of one paradigm towards the fortress of another paradigm: "your [paradigm] is conservative and promotes discrimination and inequality - and yours is radical and promotes conflict (...)"; "yours is blind to central changes - and yours is blind to the obviousness of order; "yours is idealistic, utopian, out of touch with reality - yours is the same (...)". And so, the battle of paradigms goes on. 12

This very apt interpretation of the war of discourses in a pluralist world made me commence studies on contemporary paedagogical thought from this very perspective, in order to see in them what is praised by their creators and voided by their critics as unwanted under conditions of Polish democracy. ${ }^{13}$ The trans-formation threshold in Poland after 1989 challenged academia to open up to new, hitherto unknown basic paradigms in open society education. To see the project of innovative (alternative) education in the context of competitive mobility that has the task of giving rise to mutual exclusion of paedagogical methods struggling to obtain the place "at the core", and not the "outskirts", to have the first say in explaining and valuing education, to exclusive promotion of a specific

12 Z. Melosik, Wspótczesne amerykańskie..., ibidem, p. 173.

${ }^{13}$ B. Śliwerski, Wspótczesne teorie i nurty wychowania, Kraków: Oficyna Wydawnicza "Impuls" 1998 (9th edited and expanded edition, 2015); idem, Pedagogika dziecka. Studium pajdocentryzmu, Gdańsk: GWP 2007; idem, Wspótczesna myśl pedagogiczna. Znaczenia. Klasyfikacje. Badania, Kraków, Oficyna Wydawnicza „Impuls” 2009. 
"version" of reality - it allowed me to avoid working with innovators of the fundamentalist (totalising) role of individual solutions in education. The competitive perspective of alternatives in education or paedagogy must have led to mutual enmity (e.g. ideological, personal, institutional) and depreciation of opposing views as being devoid of (scientific, ethical, political, etc.) value.

Irrespective of the paradigmatic disputes giving rise to the necessity of changes in education, in the beginning of the political transformation in Poland there emerged the problem of their core, scope and quality. It is thanks to treatises by Z. Melosik one can recognise in studies of models of teaching, to what extent the change to be designed with their use takes a modernist or postmodernist shape, if with respect to the latter, the categories of difference, otherness and diversity take to the foreground. In politics of reformation of education we clearly see the conflict between the struggle of the ministry of education to clarity, unambiguity, the educational ordering of the world, in which "one knows what to do" (or - which is essentially the same - they believe they know), in which one knows how to calculate the probability of an event, and one knows how to improve or reduce such probability; a world, in which the relation between specific situations and the effectiveness of certain actions is more or less fixed, hence, it allows one to rely on past successes as direction signs towards future successes ${ }^{14}$, and the contemporarily not avoidable any more ambiguity of educational situations, including structural and programme solutions and related innovations.

In open, pluralist societies, no government attempting to control education according to a "top-down" strategy has any chance of self-implementation, as it will face the wall of opposition by those who do not accept, respect or to a certain extent even do not like this government. This applies to all governments - leftist, liberal or conservative. Over the course of more than 27 years of political transformation in Poland after 1989, politicians have still not

14 Z. Bauman, Wieloznaczność nowoczesna. Nowoczesność wieloznaczna, transl. by Janina Bauman, Wydawnictwo Naukowe PWN, Warszawa 1995, p. 12. 
learned that as a result of elections they are to rule a country, but not the souls of its citizens and their children, much less over teachers professionally prepared to work with them. I rarely get the chance to meet professor Z. Melosik and to jointly discuss fundamental issues for paedagogy as an educational or extra-scholar science and practice, which were first devastated during Nazi totalitarianism, then during Soviet totalitarianism, with the ensuing inability to depart from the leftovers of the homo sovieticus until today, despite the ongoing political and sociocultural transformation. Thanks to the fact, however, that his treatises are written with scientific distance to the reality of our education and science, they are universal, timeless in character.

\section{Pop culture contexts and implications for body and health}

Zbyszko Melosik counts among the few Polish paedagogues who are interested in the body as a pop culture phenomenon. He published a treatise on just this subject, placing the category of the body and of health in the society of consumption, at the same time fusing his own research with those being conducted at the same time by other scientists. In his treatises, he describes selected cultural changes in the contemporary world and interestingly presents discussions concerning the implications brought about by them (potentially) for education theory and practice. Thanks to constant transgression of research fields that he partakes in which would seem reserved for (positivistically) autonomous sciences, we are able to more deeply enter this discourse to include new perspectives and modes of research. Who was unable to feed his cognitive sensitivity with the perfect analysis of societal modes of construction of identity by youths, in particular with respect to femininity and masculinity ${ }^{15}$, may fill this emerging "hole" between the world of paed-

15 Z. Melosik, Tożsamość, ciało i władza. Teksty kulturowe jako (kon)teksty pedagogiczne, Wydawnictwo Edytor, Poznań-Torun 1996. 
agogy of health and the world of everyday youth life with a further confrontation between modern and postmodern thinking.

Considering the issue of body and health, common for the entire volume and its authors, we can clearly see a specific arrangement of cultural locations and practices, which the modern man engages their psychological and social energy in. As the head of team studies and editor of the publication drawn up on their basis, he aptly interpreted human passions, capacities, forms, designs and objectives of human engagement centred on what only seemingly looks permanent on the "map of significant meanings". In his text entitled Teoretyczne problemy promocji zdrowia $i$ edukacji $z$ drowotnej [Theoretical problems of promotion of health and health education], he performs a meta-theoretical study of health discourses in contemporary society. In this volume, he also notes the body and health as being included in popular culture texts, when he presents a series of epistemological openings of post-modern culture and politics in consumerist societies. At the same time, it is his encouragement to look at their sources, substantiations and implications. He vividly characterises this post-modern world of consumption to move on to the deconstruction of such modern discourses as: McDonald's, identity and health; Coca-Cola: a soft drink as a "model" of life and identity; The tyranny of being thin and its consequences; Plastic surgery, the body and identity.

The area of the most personal and intimate sphere of human life, sexuality, is uncovered by Z. Melosik in course of an analysis of cultural and social sources, contexts and consequences of introduction to the pharmaceutical market of the newest cure for impotence - Viagra. He writes about it together with M. Cylkowska-Nowak not stopping at making available this quite "hot" discourse on this medicine as a unique phenomenon of questioning the rule of man in public and private life, but at the same time making available the results of his own surveys among studying Poles. They confirmed a range of 'cultural anxieties' prealent among the respondents. In a further joint text as well, entitled Contemporary youths: the body, 
health and popular culture ${ }^{16}$, they present the results of research among academic youth that were aimed at grasping, how the young generation in our country perceives their body and what is their attitude towards its "ideal", television hosts (models), the world of fashion and plastic surgery. The life style analysis accompanying these diagnoses confirms just how dearly our education system needs a significant turn in the pro-health education and schooling of the young generation, which eats badly, does not exercise, is dependent on substances, sick and care-free or overworked, and at the same time - unaware of all the hazards that stem from this lifestyle.

Finally, brilliant texts by Z. Melosik concerning the health and identity profiles in advertising: the Marlboro Man and the Virginia Slim Woman represent advertising mechanisms and strategies that lead to a reorientation of society's lifestyle to fit the pattern, form and image of products promoted by the media, to the creation by these of a world of illusions, dreams or desires. He uncovers alongside the hidden dimension of advertisements, as texts, the creators of which, reacting to societal trends, inscribe with cultural "traps" of consumer dependencies. The results of survey studies that apply to the perception of advertisements of tobacco products by Polish youths become perhaps the ultimate alarm signal for education scientists in order for them to work on anti-advertising education that would make youths sensitive, or perhaps, that would desensitise against this veritable "virus" of consumer culture.

As my academic experience shows, teachers are not particularly interested in works by multiple authors, being used to monistic interpretations of paedagogical theories from the time of the People's Republic. At the same time, the time of socio-political transformation in our country was best utilised by these academic institutions, in which multi-dimensionality is sought and publicised for a specific educational problem that would seem to be homogeneic in terms of content. This definitely includes health and the body,

${ }^{16}$ Ciało i zdrowie w społeczeństwie konsumpcji, ed. by Zbyszko Melosik, Wydawnictwo Edytor s.c., Toruń-Poznań 1999. 
about which Z. Melosik rightly writes that it is not possible to formulate their single, "ultimate" and culturally universal definition. After all, these are not states that are exclusively "objective", which are 'given", but - largely - social constructs ${ }^{17}$. Hence, it is not permitted to ascribe the promotion of health only to those schools that were included in the Schools for Health in Europe Network, executing in the years 1992-1995 Poland's programme under the patronage of Poland's Institute of Mother and Child. This idea may be implemented in diverse educational communities, small and large public or private schools, the paedagogical staff of which rejected the biomedical concept of the body and of health.

In the search of education promoting health and properly perceived corporeality of children and youths as well as their teachers, no "slogans" are necessary that might lead to the "objectification" of clients or that might make them just a "special" or an addition to obtain from the state or commune budget more financial resources, but they should be solutions that guarantee everyone the right to make decisions on their own "corporeality". Every Polish school should be an environment of health and of the respected human body. One should become aware of the type of paradigm, health discourse and promotion the designed changes, innovations or experiments should be part of. If we would use this to contain a functional-structural approach, then the category of health becomes a claim against teachers to perform such investments in "human (pupil) capital" so that in the future they could provide "repayment" and "profit" as "dividends". In this respect, the promotion of health boils down to the promotion of rational health behaviour that corresponds to standards and recommendations developed by medical doctors, and pupils are supposed to adhere to them without remarks. In course of health education oriented in this way are subjected to permanent control, manipulated to fit in with educator expectations. On a sidenote, schools of this type employ teachers who deny with their behaviour or actions the standards imposed on

17 Ibidem, p. 7. 
pupils (e.g. diet) or the practices of healthy everyday lives (e.g. because they smoke tobacco or drink alcohol, etc.).

A different cognitive paradigm characterised by Z. Melosik is the theory of economic and cultural reproduction, according to which health and the body are a commodity that can be bought and sold, hence, they are not available for everyone. A school promoting health thus legitimises the imposition of cultural arbitrariness of the group dominating a specific community, thus confirming the presence of social inequalities in this regard. Education becomes powerless against social, cultural and economic differences or divisions among children and youths or their socialisation environments, stubbornly trying to impose the required (healthy) life style on everyone, as if everyone did actually have equal access to it. In light of critical theory, in turn, the discourse of health and body may be an area of struggle for liberation from domination, injustice and alienation for the benefit of objectification of teachers, pupils and their parents in the care for a change to the own status quo, for a better condition of health and of the body. This support of free individual and collective will to shape competences in terms of constructive social criticism through education is awakening among all entities of the learning process of the awareness of own and social rights in this area of their lives (e.g. patient rights) and awakening criticality of thinking about institutions that strip individuals of their own activity or the ability to act.

A different discourse in health promotion education is pragmatism, in light of which the status of truth about health and its promotion is ascribed on the basis of functionality of a specific form of knowledge. The value of health and the body is socially constituted, being dependent on the time, place and on the circumstances. It is thus important only if it proves itself positively in action. However, from the point of view of a further discourse, which is - according to Z. Melosik - poststructuralism, the core of the struggle for the health of healthy life is the production of meanings and the imposition of these as valid, in line with the power relations present in society. Within the context of assumptions of poststructuralism, it is nec- 
essary to answer the following questions: why such a place and time are dominated by these and not other modes of perception of the "body" and the issue of "health"?; what is the source of new discourses in this regard?; why do people (sometimes radically) change their views on the subject?18

In a period of preparation of new curricula, Melosik's book should become the source of greatly valuable inspirations to construct "intersubjective education paths" that are so dearly needed by the young generation. thanks to this, one could help pupils to improve the levels of their own awareness in making choices and in social practices related to their body and health, so that they could proceed in their personal and adult lives logically and rationally. As Z. Melosik rightly assumes in this work, (...) the body and health should be perceived not only in biological and medical categories, but also in cultural and social ones ${ }^{19}$, and if so, then who knows, perhaps in a sense they will dominate the core and objectives of general school education in the 21st century.

Interdisciplinary treatises by Polish scientists on still other phenomena of our daily lives that is content, events, processes and actors that become popular culture, that is: tradition and postmodernity, art and technology, humanum and cogito, education and socialisation, sacrum and profanum, etc., have become the subject of a different work edited by Z. Melosik. ${ }^{20}$ It was these that provoked the creative utilisation of domestic researchers, inspired them to undertake own research, in order to, using a language that is partially isomorphic with respect to reconstructed popular culture, open us up to its "consumption", ,relishing in it", , experiencing it" through the lens of own reflection and biographical experiences, in order to see in this a message for broadly understood education. The content included in this monograph migrates to various fields of research interests of specialists in social sciences. What is interest-

18 Ibidem, p. 20.

19 Ibidem.

${ }^{20}$ Kultura popularna: teksty, rekonstrukcje i interpretacje, ed. by Zbyszko Melosik and Agnieszka Gromkowska-Melosik, Poznań 2011. 
ing is that what is only sketched out, marginal for one author, yet still perceived as a veritable sign of popular culture, another expands upon it and considers it key for the understanding of what they perceive in others as being less significant. It is thus clear how everyone complements everyone else despite the fact that this is certainly not a purposeful effect, even if it was provoked by a publication's editors by a thrilling debate.

Accordingly, a further collective work of the education scientist of Poznan charms with the style of its narration, frequently moving on to essay-like descriptions and explications of interesting phenomena, at the same time, being aware of processes that become invisible rites of our identities. The authors handled very well the recognition of socialisation and education aspects of what seemingly should remain outside of the scope of research interests of scientists. Travelling is important in our lives (as they tend to educate), significant are issues of our identity, the feeling of own value and respect in light of pressure of our corporeality that remained taboo for years, accordingly necessary is the spiritual sphere and the sphere of life successes, necessary are social ties in light of the mediocrity of pragmatic orientations of life, etc. Thanks to Melosik, the authors of this volume take on issues that hitherto slipped away from the hands of researchers as being less important. And now, thanks to methodologically correctly executed studies, we are able to understand how many events are there in our daily lives, the significance of which is existential for the processes of education, socialisation of identity, professional development or existential dilemmas of persons of various ages (from childhood all the way to the age of slipping into senility - as D. Demetrio wrote ${ }^{21}$ ). It is worthwhile to enter their educational reasoning.

The authors of articles know their research fields very well, utilise metaphor with great erudition, make use of analogies, comparative or historical and philosophical references. The superficial,

${ }^{21}$ D. Demetrio, Edukacja dorostych, [in:] Pedagogika. Subdyscypliny wiedzy pedagogicznej, ed. by Bogusław Śliwerski, Gdańsk: GWP 2006, p. 145. 
fragmentary, soft and mediocre in the pop culture world is covered by them from the position of high culture, however, without the presence of mass culture or its positive influences on the civilisation process being questioned. Everything may be pop in our world, and that is why these kinds of analyses force us to look for limits, the outline of which allows one to see the presence and the animation of high culture, intelligence, mastery instead of banalisation, the destruction of timeless values, populism and the flicker of meanings. If this author's diagnosis is correct in that pop culture time is short, when it is the more worthwhile to capture the changes that occur within it and the events that make it up, so as to have the opportunity to bounce back from the bottom. After all, the limit is the space that separates what is known from what is not (yet) known. Thanks to such a treatise, the difference between what is culture and what is pop culture becomes ever clearer. We return in this volume, as if after a very long journey around the world, to the foundations of development of culture. If pop culture takes its place in the numerator of the fraction of our existence, then the world of the European civilisation, based on, among others, Christian values, is found in its denominator.

The newest book by Zbyszko Melosik, entitled „Kultura popularna i tożsamość młodzieży: $w$ niewoli władzy i wolności" [Popular culture and youth identity: Enslaved by power and freedom $]^{22}$ does not leave us passive with respect to issues of transgression of pop culture to our daily lives, including areas of life that were hitherto reserved for high culture only. Thanks to his analysis of the newest social theories we will understand, just how important a role this knowledge may play in the construction of education studies and the interpretation of their results. The participation of an entity in popular culture, the fact that our daily lives are permeated by it, becomes a challenge for high culture, meaning, for education as well, which must cope with this aporia of reproduction of high culture as consti-

22 Z. Melosik, Kultura popularna i tożsamość młodzieży. W niewoli władzy i wolności, Kraków, Oficyna Wydawnicza „Impuls” 2013. 
tuting the ultimate form of civilisation heritage. The content of this book is so well-designed and has such a dynamic of materially differentiated narration that we are able to taste even the most refined (spiritual) content of cognitive theories or models that, it would seem, are only reserved for true connoisseurs.

According to the theory of socio-cultural homology, this treatise will be read by those who seek to confirm their high status, and are just "hungry" for own cultural arbitrariness. And this is exactly the objective, because it is not for academic lecturers or students that affirm practices typical for lower classes, despite them wanting of or holding higher education diplomas. The author, however, sows in us disquiet as to whether or not it is really so that the objective of the contemporary school is not to equip pupils with tools to allow them to relish in any works of culture, but to prepare them to pass tests that are only in place to measure their superficiality and the randomness of their knowledge and skills?

The richness and logical selection of content allows one to read cultural codes that hitherto were hidden and weakly promoted in education. Melosik writes his books in such a way that we read them with the passion of football fans watching their team play. Once again, we are able to participate in a "match" of high culture with pop culture for the value of education, refereed by the author, ensuring adherence to canonical rules of play of "the players on each team" and their interpretation. As usual, we receive a meal for the soul meant for the omnivorous that will satisfy the most demanding of desires. However, unlike the tasting of and relishing in beer, in order to receive the content fully one has to have their ",taste buds" prepared. It is doubtless also a book for those who (...) struggle to demonstrate and show the priority of their own life style over the life styles of other classes through the determination of cultural forms that they represent with the designation «canonical», «legitimized».23

And finally, this treatise provides us with an answer to the question, to what extent popular culture, cultural texts, condition the

${ }^{23}$ Ibidem, pp. 31-32. 
freedom of (re)creation of our identity. The author returns here to issues touched upon earlier, to expand upon then and update his work, for instance, speaking about fast-food corporate invasions of the world of our consumption, illusory methods and means guaranteeing alleged happiness, life success or a way out of depression, all to feed the thus-created level of narcissism. The ultimate part of the monograph is excellent - it concerns the regulation and control of identity in contemporary society, as it discloses to us the processes, mechanisms and socio-technical activity of authority in democratic states that in a hidden manner strip citizens of their subjectivity, of real influence on social, cultural or political processes.

What Z. Melosik writes about is the last call for Polish elites that they should stop consuming temporary goods that stem from their cooperation with authority if the effect would be an increased intensity of removal of national, cultural, religious, etc., identity from their own society. On the one hand, the question arises as to whether the identity of any one of us is really designed to live in the neoliberal slavery of the politics of authorities that boast freedom and in reality seek to limit it surreptitiously? This education scientist from Poznań shows what is written in Western Europe by famed economists and political scientists, namely that a specific type of fascism is returning in the form of extreme statism, meaning, a [political] system, in which the state dominates the individual and all private organisations ${ }^{24}$.

It is sufficient to take a closer look at the bureaucratisation and institutionalisation of the lives of citizens continuously expanding within Polish society, as citizens are stripped of their own identity as a result of domination of processes of standardisation of lives of children and youths from the time of preschool already, and through the application of legal norms in adult lives as the sole modes of adjustment of daily lives. The juridisation of cultural, education but also emergency rescue or health promotion or protection processes violates the fundamental liberties of man under the guise

${ }^{24}$ See J. Goldberg, Lewicowy faszyzm, Poznań, Zysk i S-ka Wydawnictwo 2013. 
of caring for their development. Subordinating man and reality to indicators becomes a hidden mode of authoritarian governance that fakes our liberty in the space of its illusions. What is worse, the boundaries between science and expert opinion that becomes ever more strongly subordinated to commercialisation of knowledge, resulting in a flight away from responsibility for one's opinions or reviews of the actions of the authorities or its designs by experts loyal to those in power.

Melosik aptly forgoes the valuation of any sort of subdivision into high/ low culture. The removal of valuation of both types of cultures has a point, as long as it does not threaten the feeling of community of cultural identity in the family environment. I do not want to enter into a discussion here, but I believe that only encouragement to conclude that low culture is not lower, describes continuation of remaining in the illusion of being open to it; and one must remember that through low culture, values of high culture may be implemented. Thus, the category of delay of valuation to the extent allowed of parents, teachers in light of their levels of tolerance (Lat. tolero - cope with what is different) allows one to return to their own identity that they need not change, that they need not be in conflict with, but which they may allow to travel into a world of other values or other experiences, without needing for these to be acknowledged by us or by those under our care as being our own forever.

Any sort of delay allows the transposition of civilisation values in the part that is truly universal, timeless. Social constructivism need not necessary lead to a "point of paedagogical helplessness", but at most to a "hesitation", because, helpless is one who is not convinced as to their own values, so, they start to lose faith in them, or rather in the basis of their own identification with respect to them. Perhaps facing popular culture, those originating in high culture could only strengthen and not weaken our identities if we become aware of what we are able to do or what we are already losing, or what was not part of us because we did not understand, not accept it fully. The core of identity is also decided upon by primary socialisation and its secondary overlays, hence, paedagogy may provide not as much sources, 
because these rest in the family, in the natural environment of origin and life, but rather arguments, experiences, stimuli that will reinforce, strengthen or exclude them to be replaced by inversion - with antiidentity. In public discourse one can read the question, how is it that a citizen of the US or the UK becomes an Islamic terrorist? The paedagogy of struggle with a specific shortcoming of the world is weakly developed, barely sketched out, and it may have two faces. Here we have an unemployed person, stripped of any chance of living a decent life, despite being educated, healthy, powerful, despite having aspirations, etc., who enters into a life of crime because they conclude that this world does not fit in with their needs.

It is an enormous advantage of this book that Z. Melosik closes it with a description of his own attitude or even a paedagogical settlement with reality, in which, after all, he also lives, and in which he created for many years works for further generations of education specialists and broadly understood researchers in social sciences. I do not hide the fact that I haven't read for a long time a treatise that would be supported by arguments so well, that would use the newest sources of international research on post-modern societies and the pop cultures developed in them with a greater or lesser loss for our civilisation.

\section{Sensitisation to academic pathologies}

Higher education, in particular its key function and responsibility for scientific research, remains at a stage of organisational and programmatic, administrative and legal as well as economic changes that are hidden as revolutionary, but which in actuality do have this magnitude, and as a result of which its functioning experiences grave disturbances. This is not the first revolution in the history of universities and higher education facilities (medical, technical, agricultural, economic ones, etc.), but it permeates ever strongly and quickly into deep axionormative, missionary structures of Polish facilities as well, thus delineating for them the structural framework 
of "necessary" changes. These impact first the organisational and economic basis for higher education, forcing it to adapt the cultural core, related to the sense of scientific research and the education of academic ranks for their purposes, to alleged market expectations. An ever more stronger shift is seen away from a higher education and science model rooted in European culture, meaning, from the model of Humboldt, to the pragmatic, Anglo-American model, which subordinates science and academic education to demands of the market economy and the bureaucracy that feeds itself on it, and the related control of supply and demand.

We are thus seeing a reduction of scientific facilities that have been constructed for years, frequently continuing century-long traditions, to be replaced by temporarily existing research teams, the main binder for which is the economical, technological or sociotechnical factor, and not timeless values of willing to attain the truth. Scientists must thus answer the question, whether and to what extent they consider it proper to participate in education and research work, in which the historic model of relations between the master and the student fades away, to be replaced by deconstruction of sense and subjects? Do changes related to the process of education, its internationalisation in the spirit of the declaration of Bologna, the unification of diploma validity, the increase of flexibility in the designation of didactic programmes, international exchange and the execution of research projects really have to violate national schools and academic communities that are fundamental for scientific research?

Without a doubt, my interests in the hospital of academic paedagogy were a derivation of Z. Melosik's scientific treatise that was entitled - Uniwersytet $i$ społeczeństwo. Dyskursy wolności, wiedzy $i$ wladzy [The University and society. Discourses of freedom, knowledge and authority].25 Written with incredible analytical and synthetic talent, the treatise on social changes in terms of functions

25 Z. Melosik, Uniwersytet $i$ społeczeństwo. Dyskursy wolności, wiedzy $i$ władzy, Poznań, Wydawnictwo WOLUMIN 2002. 
and roles of the university turned out to have been published in a moment that was very important for Polish academia and education policy, as on the one hand it became a part of the social debate on the project 'Strategy of development of higher education in Poland until 2010', initiated by the Polish Ministry of Education in the year 2010, and on the other hand it responded perfectly to a range of dilemmas in terms of the ongoing discussion about the quality of higher education. This treatise was published in the same year that the Polish University and National Accreditation Commission were called into existence. It cannot wonder as to why the core idea of Z. Melosik was the discourse category that remains at the core of the analytical concept of M. Foucault and is understood as a system of knowledge, concepts or thoughts, incorporated in social practices and occurring in the real world.

Social discourse on university education can thus be treated as a specific type of legitimisation of paedagogical knowledge and detailed educational practices (paedagogies) that correspond to it. It is hence that, which provides university education subjects with a diagram, a pattern of thinking about it. The subjectivity of persons is thus the product of discourses in which they exist, and which are pronounced from various places. Some are privileged through discourse, others discriminated. Discourse is an indivisible configuration of authority-knowledge (and not of authority and knowledge). Within knowledge there is authority, and within authority there is knowledge (who has authority - has knowledge, and vice versa). Every truth in the humanities is the result of authority, and through this it is not objective. The possibilities of expression by persons of the meanings of concepts or words and of their definition are limited by the social position taken up by them (in society and in institutions). Discourse may thus be both an instrument as well as the effect of authority, but also a hindrance, a trap, a centre of resistance or finally a vantage point for an opposing strategy.

In contemporary paedagogy, the analysis of significance of discourses of freedom, knowledge and authority as conducted by Zbyszko Melosik allows one to perceive the university as an educa- 
tional institution that produces and legitimises them or that limits the 'right to speak'. Discourse expresses itself not only with respect to university, but it is also interested in the form or uniqueness of its education offer depending on the socio-political context as offered by this type of facility. It is universities that have fundamental meaning for the dissemination and selective publication of discourse and their societal internationalisation, controlling access to them. Hence, following the analysis of contexts of operation of universities as chosen by Z. Melosik, it is thus worth it to take a closer look at just how much liberty, authority and knowledge there is thanks to them. The author recreates in this treatise the state of mutually opposing ideologies, concepts and theories of higher education depending on changing socio-political conditions.

It is not significant that in case of the majority of his paths, he refers to US and UK reality, because - as he rightly notes in the introduction - they can also be used to refer to the Polish situation. The greater is the merit of this leader, not only for education science, from Poznan in that he demystifies for Polish readers the myths at play that they have been "fed" for years on the alleged americanisation of higher education. One could thus ask whether we are really not only societally but also institutionally compared in this area of the nation's life and development? Thanks to the treatise by $Z$. Melosik, the issues fundamental for university education were accentuated with unique clarity; these are:

- What is the role of the university in the society of knowledge subjected to processes of globalisation?

- What are the criteria of academic freedom? What end should it serve, what should it provide? What does it limit/ what must limit it?

- Who and using what criteria is to define the "progress of knowledge"? What are the standards of legitimisation and dissemination of "true knowledge"? What is, in essence, the academic canon?

- To what extent may entities financing university operation defend or reduce academic freedom? 
- What is the impact of relations between scientific knowledge and personal knowledge of the academic teacher on the education of students (hidden or undisclosed)?

- What conditions must be fulfilled in order for the knowledge collected within a university to have the status of universally significant knowledge?

- What consequences for academic functions of universities are carried with the departure from their autonomic status towards market orientation or the bureaucratic model?

- What influence on the quality of university teaching does real care for standards and levels in the area of academic promotion have? What really hides behind academic advancement procedures?

- How will the role of the academic lecturer change? etc.

The acquisition of scientific identity always requires a "mirror" that is the academic community. The reconstruction of practices and criticism of the tenure system conducted by Z. Melosik, or the procedures of academic progress at United States-based universities forms a uniquely current part of the Polish debate on the domestic procedures of acquisition of scientific titles and degrees and the institutions that guarantee their correctness! Various approaches, paradigms and discourses are becoming significantly important for the contemporary social and legal debate surrounding the prepared, yet another update to the Polish act on higher education and scientific degrees and titles, which in this community form in essence a form of struggle for status and the ability to do science at universities, in particular in terms of humanities. Z. Melosik was not without reason a member of the Polish Central Committee for Degrees and Titles, and now belongs to its most valued and respected superreviewers.

His book should primarily be read by university scientific staff, education system authorities but also politicians or students. The latter the more so that they may recognise mechanisms of commercialisation of higher studies and their implications in non-state and state education. This treatise should be a scientific aid in the politi- 
cal, parliamentary debate on the necessity of changes in the process of financing of science and higher education in the Third Polish Republic. Zbyszko Melosik shows here very dangerous consequences for the development of universities and science, in the form of the economic factor in academic life aver gaining importance and significance within the knowledge or knowledge-based society (commercialisation of higher education). Writing about the social functions of universities, he was able to show in this book the influence of academic education and diplomas on the future biography of the individual and on processes of social stratification. This provides us with a grand argument in the ongoing debate on the role of higher education in the process of equalisation of the education opportunities of youths, in the maintenance of development of its ubiquity and availability.

The above book enriches Polish subject literature, particularly in the area of sociology of education and comparative paedagogy, offering entirely new contexts and theories as well as critical reflection on their applications in the West, liberating us from "local emotions" and elevating the "objectivism of the debate" in academic circles and in society. This a unique treatise that does not have a counterpart in our country, hence, it traces a path to freedom and to a structural diagnosis of contemporary changes of the university as an institution, the functions and forms of which are not so obvious any more. At the same time, it forms a kind of call to a reform of the traditional "education theatre", sensitising society to an increase of moral sensitivity with respect to this temple of wisdom.

\section{Comparative studies in paedagogy}

Doing research in the area of contemporary paradigms, streams or paths in paedagogy, it is worth starting with a search for an answer to the question, what every one of them is or is not, how are they defined and where to seek sources of their uniqueness. One cannot deal with comparative studies of thought without studying the 
works of Z. Melosik. One of his recent monographs, entitled Teoria $i$ praktyka edukacji wielokulturowej [Theory and practice of multicultural education ${ }^{26}$ consumes in a sense perfectly his numerous world trips. Knowledge is a text created by someone under some circumstances, transporting some unique individual cognitive perspective, dependent on the conditions of its construction. In it, he masterfully deconstructs, but also criticises or even redefines, certain conceptual categories so that we would be able to understand that a text has its randomness and fragmentariness, purpose and integrity. Zbyszko Melosik is able to disclose the workshop used to construct and deconstruct contemporary theories and practices of multicultural education, with the knowledge of the art of comparative studies, as few others can. The construction of narration in this treatise is complex, multi-level, very broadly expanded and supported by a logical substantiation of arguments. The monograph has clear cognitive values as it introduces us to a world of education theories and solutions in perspectives of multicultural education that are weakly recognised in Poland, from countries such as the United States, Australia or Spain. In this, he does not hide his sensitivity to phenomena and senses of actual functioning of specific solutions within them.

It is impossible to analyse today the wealth of comparative studies in paedagogy along with its subject of research without referring to this book as well, as it contains not only well-chosen examples of the the phenomenon of multiculturality in education, but also because that it discloses disputes concerning the core and the scope of entanglement of the processes of education in ideologies and politics as well as in cultural changes that take place within the area of metatheory. Once again, the education scientist enriches Polish subject literature, in particular in the area of sociology of education and comparative paedagogy to include all new contexts and theories. He shows just how one should go about doing critical reflection on the applications of these paedagogies across three continents, to also

26 Z. Melosik, Teoria i praktyka edukacji wielokulturowej, Kraków: Oficyna Wydawnicza „Impuls” 2007. 
liberate us from "local emotions" and raise the "objectivism of the debate" in academic circles and in society. Particularly today, in light of the unique reinforcement of migration movements from Arab states that are burdened by war, it becomes clear that not all politicians study sufficiently thoroughly issues of intercultural drama and conflict.

Just as researchers in history have to conduct very tiresome comparative studies in archives, collecting relevant documents and traces of existence of specific phenomena, $\mathrm{Z}$. Melosik also conducted very difficult, time-consuming and thorough studies on subject literature distributed across foreign libraries so as to capture in every locality, in every region and nation what is becoming global, what is becoming a part of the community of experiences and thoughts and what makes the difference. It is a grand study demystifying United States culture and the logic of staging reality produced by the media, the fragmentation of identity in the consumption society and the commercialisation of ethnic cultures. With a narration that is characteristic for its style that is very colourful and welldocumented by scientific sources, he describes to us the permeation of multi-cultural relations and experiences not only into politics, but also to education and to everyday lives. It is thus clear that his treatises may be used not only by students of paedagogy, sociology or psychology, but also cultural, earth or political sciences.

Finally, one should note the very interesting reconstruction of the methodological basi in contemporary world humanities that apply to the structures of the scientific field of each discipline within social sciences. The author expands upon our knowledge on new paradigms emerging in the discoursive debate, for instance, the "pastoral paradigm" or the antifundamentalist paradigm. The heterogeneity of contemporary scientific debate thus delineates a new field to proponents of science. After all, they have to handle not only new epistemological ideas but also analyse in detail the consequences of the theoretical position reconstructed by them. Without a doubt, the most interesting instance in his examples of regional and education identities are those that apply to contexts and con- 
troversies of Australian multicultural education. All this makes Z. Melosik's treatise a work that one cannot put down, experiencing within it the author's cognitive fascination and - what is uniquely important - a uniquely balanced, distanced and responsible analysis of the studied phenomena. We find in this book a response to the question on just how could multicultural paedagogy react to the gradual "dissolution" or dispersion of ethnic and racial identities in the ever-present discourse of consumption.

Nobody among contemporary paedagogues is able to write about difficult things using a simple language and about seemingly simple, everyday issues - in a philosophical and deeply cultural manner, as Zbyszko Melosik is able to write. In his analysis of issues of inter- and multiculturality as well, he awes us with the ability to read a foreign culture, and at the same time encourages one towards a reflective journey, to transgress to other cultures in a tactful manner, with authentic respect, and without any sort of violation of the own identities of its relevant representatives. This book is a further pearl in my library, as it binds within itself the subtle, very personal culture of the author meeting Another, a different world, with a unique capacity to find within it everything that may be close or common to us. Just like the "Little Prince" of Polish education science, Z. Melosik acquaints us with the culture and education of three continents, describes to us the conditions of formation of the identities of individuals and ethnic groups that, living in a situation of "difference" and "uniqueness" were to a certain extent thrown into the maelstrom of the processes of globalisation and of possible ideological takeover. We stand before an open door leading to a labyrinth of multiculturality, and hence, within this work we receive the key to conduct comparative ethno-paedagogical studies.

As years pass, Poland is also becoming culturally diversified country. The treatise by Z. Melosik is for us not only an opportunity to prepare well ahead of change, but a veritable passport to our own consciences and culture, to the retention of our own identity that is to that or a different extent one of a "minority". This is also a perfect comparative study of diverse cultures that could serve politicians and 
paedagogues to help eliminate from the process of education of young generations the remains of fundamenalism or even ethnic or racial hate, to oppose the establishment of closed cultural and language enclaves. Fundamentalism in the humanities, and in paedagogy in particular, is difficult if, proclaiming its statements and laws as the only truth or the only reasonable, the best - even if they are frequently confrontational, opposing others - it believes that there is no need to let other scientific schools voice their thoughts, and if its theses are to be binding on all, irrespective of their acceptance. It thus takes from others away the right to own generalisation of knowledge or theory, does not allow new research perspectives, and at the same time limits the development of science. This type of power attitudes leads at the same time to the dogmatisation of the main assumptions of a given direction, pronouncing their uniqueness.

\section{Conclusion}

The scientific school is where its master is, and a master for Poznań is prof. Dr. hab Zbyszko Melosik, dean of the Faculty of Education Studies of the Adam Mickiewicz University, in his jubilee year. The internal freedom of the teacher/ master is, in the order of his being, provided to him along with his nature, but one has to agree at the same time with philosophers that in the order of perfection, meaning, in the order of participation in freedom, it was provided to him by his masters. As very few are able to - in academic circles that continue to be highly hierarchical - he could liberate himself, conquer and solidify his internal freedom, or the freedom to choose and complete the objectives he planned on, which in itself became the capacity to oppose external pressure, to provide and infect those under his care and his co-workers with internal freedom. It is thus clear that all publications by Melosik fascinate and endlessly envelop, because the care for the fulfilment of the greatest dream of 20th century humanists is very clear within them - to construct civilisations of humanum, or enclaves of love. 


\section{Bibliography}

[1] Bauman Z., Wieloznaczność nowoczesna. Nowoczesność wieloznaczna, transl. by Janina Bauman, Wydawnictwo Naukowe PWN, Warszawa 1995.

[2] Demetrio D., Edukacja dorostych [in:] Pedagogika. Subdyscypliny wiedzy pedagogicznej, ed. by Bogusław Śliwerski, Gdańsk, GWP 2006.

[3] Kwieciński Z., Witkowski L. (red.), Ku pedagogii pogranicza, UMK Toruń 1990.

[4] Kwieciński Z., Witkowski L. (red.), Spory o edukację. Dylematy $i$ kontrowersje we wspótczesnych pedagogiach, IBE, Warszawa 1993.

[5] Magna Charta Universitatum (Great Charter of Universities), Observatory Magna Charta Universitatum, on-line at http://www.magna-charta.org/resources/ files/the-magna-charta/english, access on 17.11.2019.

[6] Melosik Z., Teoria i praktyka edukacji wielokulturowej, Kraków, Oficyna Wydawnicza „Impuls” 2007.

[7] Melosik Z., Ciało i zdrowie w społeczeństwie konsumpcji, Wydawnictwo Edytor s.c., Toruń - Poznań 1999.

[8] Melosik Z., Gromkowska-Melosik A., Kultura popularna: teksty, rekonstrukcje i interpretacje, Poznań 2011.

[9] Melosik Z., Kultura popularna i tożsamość młodzieży. W niewoli władzy i wolności, Kraków, Oficyna Wydawnicza „Impuls” 2013.

[10] Melosik Z., Postmodernistyczne kontrowersje wokót edukacji, Wydawnictwo Edytor, Poznań - Torun 1995.

[11] Melosik Z., Szkudlarek T., Kultura, tożsamość i edukacja. Migotanie znaczeń, Kraków, Oficyna Wydawnicza „Impuls” 1998.

[12] Melosik Z., Tożsamość, ciało i władza. Teksty kulturowe jako (kon)teksty pedagogiczne, Wydawnictwo Edytor, Poznań - Toruń 1996.

[13] Melosik Z., Uniwersytet $i$ społeczeństwo. Dyskursy wolności, wiedzy i władzy, Poznań, Wydawnictwo WOLUMIN 2002.

[14] Melosik Z., Wspótczesne amerykańskie spory edukacyjne, UAM Poznań 1994.

[15] Nalaskowski A., Pedagogika w cztery strony (typescript of an unpublished lecture, given during the Polish Conference "Prawica-Lewica-Wychowanie” [Right wing-Left wing-Education] at the Faculty of Paedagocal Sciences of the Nicholas Copernicus University in Torun on December 5th, 2012).

[16] See J. Goldberg, Lewicowy faszyzm, Poznań, Zysk i S-ka wydawnictwo 2013.

[17] Szkudlarek T., Śliwerski B., Wyzwania pedagogiki krytycznej i antypedagogiki, Impuls, Kraków 1992.

[18] Szkudlarek T., Wiedza i wolność w pedagogice amerykańskiego postmodernizmu, Kraków, Oficyna Wydawnicza „Impuls” 1993.

[19] Śliwerski B., Problemy wspótczesnej edukacji. Dekonstrukcja polityki oświatowej III RP, Warszawa, WAiP 2009. 
[20] Śliwerski B., Edukacja autorska, Kraków, Oficyna Wydawnicza „Impuls” 1996.

[21] Śliwerski B., Edukacja pod prąd, Kraków, Oficyna Wydawnicza „Impuls” 2001.

[22] Śliwerski B., Jak zmieniać szkote, Kraków, Oficyna Wydawnicza 'Impuls” 1997.

[23] Śliwerski B., Śliwerska W., Edukacja w wolności, Kraków: Oficyna Wydawnicza „Impuls" 1991.

[24] Śliwerski B., Wspótczesne teorie i nurty wychowania, Kraków, Oficyna Wydawnicza „Impuls” 1998 (9th edited and expanded edition, 2015).

[25] Śliwerski B., Wyspy oporu edukacyjnego, Kraków: Oficyna Wydawnicza „Impuls" 1993. 